\title{
Prognostic value of c-Met overexpression in hepatocellular carcinoma: a meta-analysis and review
}

\author{
Jung Han Kim¹, Hyeong Su Kim¹, Bum Jun Kim ${ }^{1,3}$, Hyun Joo Jang² and Jin Lee ${ }^{2}$ \\ ${ }^{1}$ Division of Hemato-Oncology, Department of Internal Medicine, Kangnam Sacred-Heart Hospital, Hallym University Medical \\ Center, Hallym University College of Medicine, Seoul 07441, Republic of Korea \\ ${ }^{2}$ Division of Gastroenterology, Department of Internal Medicine, Dongtan Sacred-Heart Hospital, Hallym University Medical \\ Center, Hallym University College of Medicine, Hwasung 18450, Republic of Korea \\ ${ }^{3}$ Department of Internal Medicine, National Army Capital Hospital, The Armed Forces Medical Command, Sungnam 13574, \\ Republic of Korea
}

Correspondence to: Jung Han Kim, email: harricil@hotmail.com

Hyun Joo Jang, email: jhj1229@hallym.or.kr

Keywords: c-Met, hepatocellular carcinoma, prognostic value, meta-analysis

Received: June 08, 2017

Accepted: July 26, 2017

Published: August 09, 2017

Copyright: Kim et al. This is an open-access article distributed under the terms of the Creative Commons Attribution License 3.0 (CC BY 3.0), which permits unrestricted use, distribution, and reproduction in any medium, provided the original author and source are credited.

\section{ABSTRACT}

The overexpression of c-Met protein has been detected in hepatocellular carcinoma (HCC). However, its prognostic impact remains uncertain. We performed this meta-analysis to evaluate the prognostic value of c-Met overexpression in patients who underwent curative surgical resection for HCC. A systematic computerized search of the electronic databases was carried out. From 5 studies, 1,408 patients who underwent surgical resection for HCC were included in the meta-analysis. Compared with patients with HCC having low c-Met expression, patients with c-Met-high tumor showed significantly worse relapse-free survival (hazard ratio $=1.26[95 \%$ confidence interval, 1.02-1.56], $P=0.03$ ) and overall survival (hazard ratio = 1.16 [95\% confidence interval, 1.03-1.31], $P=0.01$ ). In conclusion, our meta-analysis indicates that c-Met overexpression is a significant adverse prognostic factor for recurrence and survival in patients who underwent surgical resection for HCC.

\section{INTRODUCTION}

Hepatocellular carcinoma (HCC) is the fifth most common cancer worldwide [1]. Despite the recent advances in diagnostic and therapeutic modalities, HCC is still one of the most lethal malignancies $[2,3]$. Surgical resection is the first choice of treatment for patients with $\mathrm{HCC}$ at early stage, but it is possible only in a small proportion of patients because of impairment of liver function caused by underlying cirrhosis or advanced disease at the time of diagnosis $[4,5]$. Moreover, more than half of the patients who underwent complete resection eventually develop recurrent diseases or de novo tumors during the course of their disease [6].

For patients with advanced HCC, systemic treatment with sorafenib or sunitinib (oral, small-molecule, multitargeted receptor tyrosine kinase inhibitors targeting receptors for platelet-derived growth factor and vascular endothelial growth factor) can be recommended $[7,8]$.
However, their survival benefits are disappointing, and thus, new effective treatments are still required. c-Met has recently emerged as a possible therapeutic target in various tumors including HCC and some drugs targeting the c-Met signaling pathway are under investigation in clinical trials [9].

c-Met is the product of the proto-oncogene $M E T$ and the tyrosine kinase receptor for hepatocyte growth factor (HGF) [10]. HGF, also known as a scatter factor, binds to c-Met and initiates auto-phosphorylation of multiple tyrosine residues in the intracellular region. The c-Met/HGF signaling pathway regulates multiple cellular functions, including differentiation, proliferation, and angiogenesis $[11,12]$. c-Met also plays critical roles in the pathogenesis of cancer. It is implicated in the molecular mechanisms of tumor cell proliferation, survival, invasion, and metastasis [13]. The enhanced expression of c-Met has been observed in various tumors, such as breast cancer [14], lung cancer [15], gastric cancer [16], colorectal 
cancer [17], cervix cancer [18], or pancreatic cancer [19]. Several meta-analyses in common tumors indicated that high c-Met expression was associated with a poor prognosis [14-18].

The overexpression of c-Met has also been observed in HCC [20-28]. However, its prognostic impact has not been consistent among studies. Therefore, we performed this meta-analysis to evaluate the prognostic value of c-Met overexpression in patients who underwent curative surgical resection for HCC. To our knowledge, this is the first meta-analysis regarding the prognostic impact of c-Met overexpression in patients with HCC.

\section{RESULTS}

\section{Results of search}

Figure 1 shows the flowchart of our study. A total of 313 potentially relevant studies were initially found, but 304 of them were excluded after screening the titles and abstracts. Of the remaining 9 potentially eligible studies, 4 were further excluded by the inclusion criteria: one was conducted in advanced HCC [20] and three had no data from which the required hazard ratio (HR) with $95 \%$ confidence interval (CI) stratified by the c-Met status (low or high) could be extracted [21-23]. Finally, 5 studies were included in the meta-analysis [24-28].

\section{Characteristics of the included studies}

Table 1 summarizes the main characteristics and clinical outcomes of the five included studies. All the studies were performed retrospectively in $\mathrm{HCC}$ patients who underwent curative surgical resection. From the 5 studies, 1,408 patients were included in the meta-analysis. One study used Western blot to assess the c-Met status [24], and the remaining 4 used immunohistochemistry (IHC).

\section{c-Met expression status}

There was a marked heterogeneity between the criteria used to dichotomize c-Met status (c-Met ${ }^{\text {low }}$ or c-Met $\left.{ }^{\text {high }}\right)$. The criteria are briefly summarized in the Table 1. The rate of high c-Met expression ranged from $25.4 \%$ [27] to $61.2 \%$ [28].

\section{Impact of c-Met expression on relapse-free survival}

From three studies [24-28], 1,356 patients were included in the meta-analysis of HRs for relapse-free survival (RFS). Compared with HCC patients with low c-Met expression, patients with c-Met-high HCC showed significantly worse RFS (HR $=1.26[95 \%$ CI, 1.02-1.56], $P=0.03$ ) (Figure 2A). There was a significant heterogeneity among studies $\left(X^{2}=7.02\right.$, $P=0.07, I^{2}=57 \%$ ) and the random-effect model was selected.

\section{Impact of c-Met expression on overall survival}

From five studies [24-28], 1,408 patients were included in the meta-analysis of HRs for OS. Patients

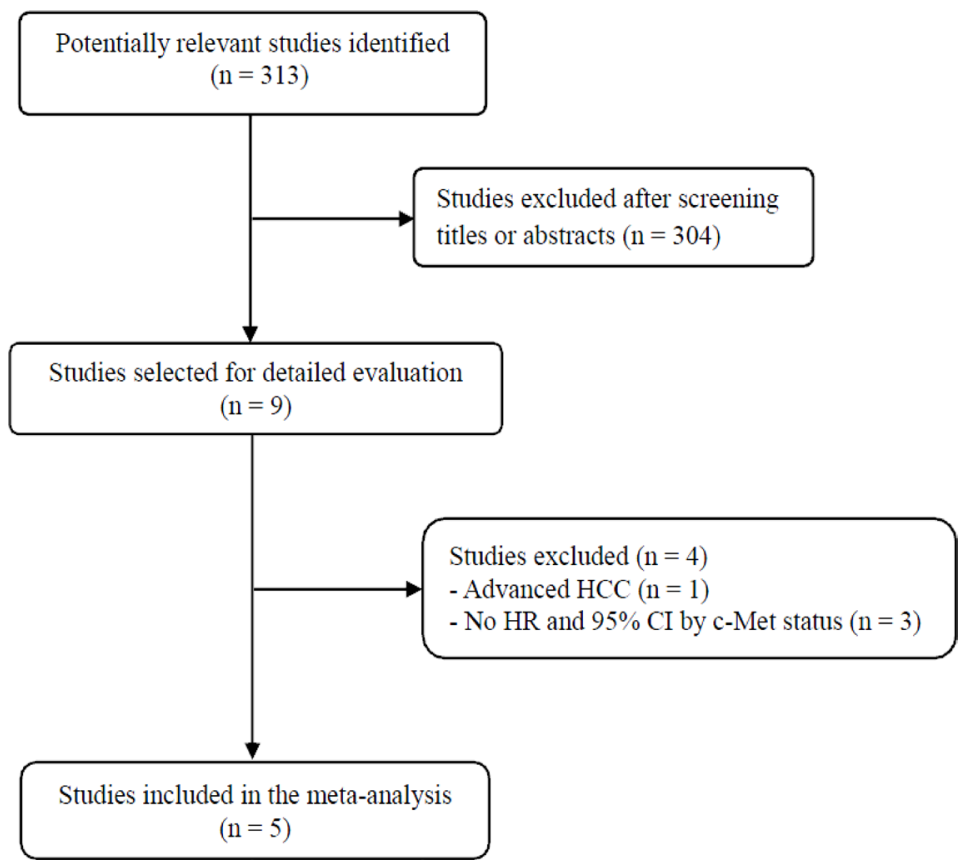

Figure 1: Flow diagram of search process. 
Table 1: Summary of the five included studies

\begin{tabular}{|c|c|c|c|c|c|c|c|c|}
\hline \multirow[b]{2}{*}{$\begin{array}{l}\text { Author (year) } \\
\text { Country }\end{array}$} & \multirow[b]{2}{*}{ Methods } & \multirow[b]{2}{*}{$\begin{array}{l}\text { Antibody, } \\
\text { Dilution }\end{array}$} & \multirow[b]{2}{*}{$\begin{array}{l}\text { No. of } \\
\text { patients }\end{array}$} & \multicolumn{5}{|c|}{ c-Met results } \\
\hline & & & & Criteria for c-Met ${ }^{\text {high }}$ & c-Met ${ }^{\text {low }}$ & c-Met high & $\begin{array}{l}\text { HR for RFS } \\
(95 \% \mathrm{CI})\end{array}$ & $\begin{array}{l}\text { HR for OS } \\
(95 \% \mathrm{CI})\end{array}$ \\
\hline $\begin{array}{l}\text { Ueki et al., } \\
\text { (1997) } \\
\text { Japan }\end{array}$ & $\begin{array}{l}\text { Western } \\
\text { blot }\end{array}$ & $\begin{array}{l}\text { Not } \\
\text { applicable }\end{array}$ & 62 & $\begin{array}{l}\geq \text { Cutoff point of median value }(36.4 \%) \\
\text { compared with the Hep3B band }\end{array}$ & $32(51.6 \%)$ & $30(48.4 \%)$ & NA & $\begin{array}{l}2.26(1.00-5.11) \\
P=0.051\end{array}$ \\
\hline $\begin{array}{l}\text { Ke et al., } \\
(2008) \\
\text { China }\end{array}$ & $\mathrm{IHC}$ & $\begin{array}{l}\text { Anti- } \\
\text { human } \\
\text { c-Met, } \\
\text { EPI1454Y, } \\
1: 100\end{array}$ & 520 & $>20 \%$ of tumor section & $238(45.85 \%)$ & $282(54.2 \%)$ & $\begin{array}{l}1.18(0.95-1.46) \\
P=0.111\end{array}$ & $\begin{array}{l}1.23(0.97-1.53) \\
P=0.118\end{array}$ \\
\hline $\begin{array}{l}\text { Lee } \text { et al., } \\
(2013) \\
\text { Korea }\end{array}$ & $\mathrm{IHC}$ & $\begin{array}{l}\text { Rabbit } \\
\text { monoclonal } \\
\text { anti-c-Met, } \\
1: 100\end{array}$ & 287 & $\begin{array}{l}\text { Proportion of stained tumor cells: } 0=< \\
20 \% ; 1=20-60 \% ; 2=61-80 \% ; 3=\geq \\
81 \% \\
\left(c-\text { Met }^{\text {high. }}: 2 \text { or } 3\right)\end{array}$ & $207(72.1 \%)$ & $80(27.9 \%)$ & $\begin{array}{l}1.099(0.86-1.41) \\
P=0.461\end{array}$ & $\begin{array}{l}1.095(0.92-1.30) \\
P=0.299\end{array}$ \\
\hline $\begin{array}{l}\text { Kondo et al., } \\
(2013) \\
\text { Japan }\end{array}$ & $\mathrm{IHC}$ & $\begin{array}{l}\text { Rabbit } \\
\text { polyclonal } \\
\text { anti-c-Met, } \\
1: 500\end{array}$ & 59 & $\begin{array}{l}\text { Membrane staining: } 0=\text { no; } 1=\text { weak } \\
\text { and incomplete or weak but complete } \\
<10 \% \text { of tumor cells; } 2=\text { weak but } \\
\text { complete in } \geq 10 \% \text { or intense and } \\
\text { complete circumferential staining in }< \\
30 \% ; 3=\text { intense and complete in } \geq 30 \% \\
\text { (c-Met }{ }^{\text {high. }} 2 \text { or } 3 \text { ) }\end{array}$ & $44(74.6 \%)$ & $15(25.4 \%)$ & $\begin{array}{l}3.10(1.49-6.46) \\
P=0.002\end{array}$ & $\begin{array}{l}0.96(0.44-2.07) \\
P=0.91\end{array}$ \\
\hline $\begin{array}{l}\text { Koh et al., } \\
(2015) \\
\text { Korea }\end{array}$ & IHC & $\begin{array}{l}\text { Rabbit } \\
\text { polyclonal } \\
\text { anti-c-Met, } \\
1: 50\end{array}$ & 490 & $\begin{array}{l}\text { Reactivity/membrane or cytoplasmic } \\
\text { staining; } 0=\text { no reactivity; } 1=\text { weak/faint } \\
\text { or light; } 2=\text { moderate/ intermediate in } \\
\text { at least } 30 \% \text { or tumor cells; } 3=\text { strong/ } \\
\text { intense complete in } \geq 30 \% \\
\text { (c-Met }{ }^{\text {tigh }}: 2 \text { or } 3 \text { ) }\end{array}$ & $190(38.8 \%)$ & $300(61.2 \%)$ & $\begin{array}{l}1.25(1.01-1.55) \\
P=0.046\end{array}$ & $\begin{array}{l}1.21(0.91-1.60) \\
P=0.199\end{array}$ \\
\hline
\end{tabular}

IHC, immunohistochemistry; RFS, relapse-free survival; OS, overall survival; HR, hazard ratio; CI, confidence interval; NA, not available.

with c-Met-high HCC showed significantly worse OS than those with c-Met-low tumor $(\mathrm{HR}=1.16[95 \% \mathrm{CI}$, $1.03-1.31], P=0.01$ ) (Figure 2B). The fixed-effect model was applied because there was no significant heterogeneity across the studies $\left(X^{2}=3.50, P=0.48, I^{2}=0 \%\right)$.

\section{Publication bias}

Visual inspection of the funnel plots for RFS and OS showed symmetry, indicating there were no substantial publication biases (Figure 3A and 3B).

\section{DISCUSSION}

In this meta-analysis, we evaluated the prognostic impact of c-Met overexpression in patients with surgically resected HCC. The results show that high c-Met expression is significantly associated with worse RFS and OS. Our findings suggest that c-Met overexpression represent a potential adverse prognostic marker in patients who received curative surgery for HCC.

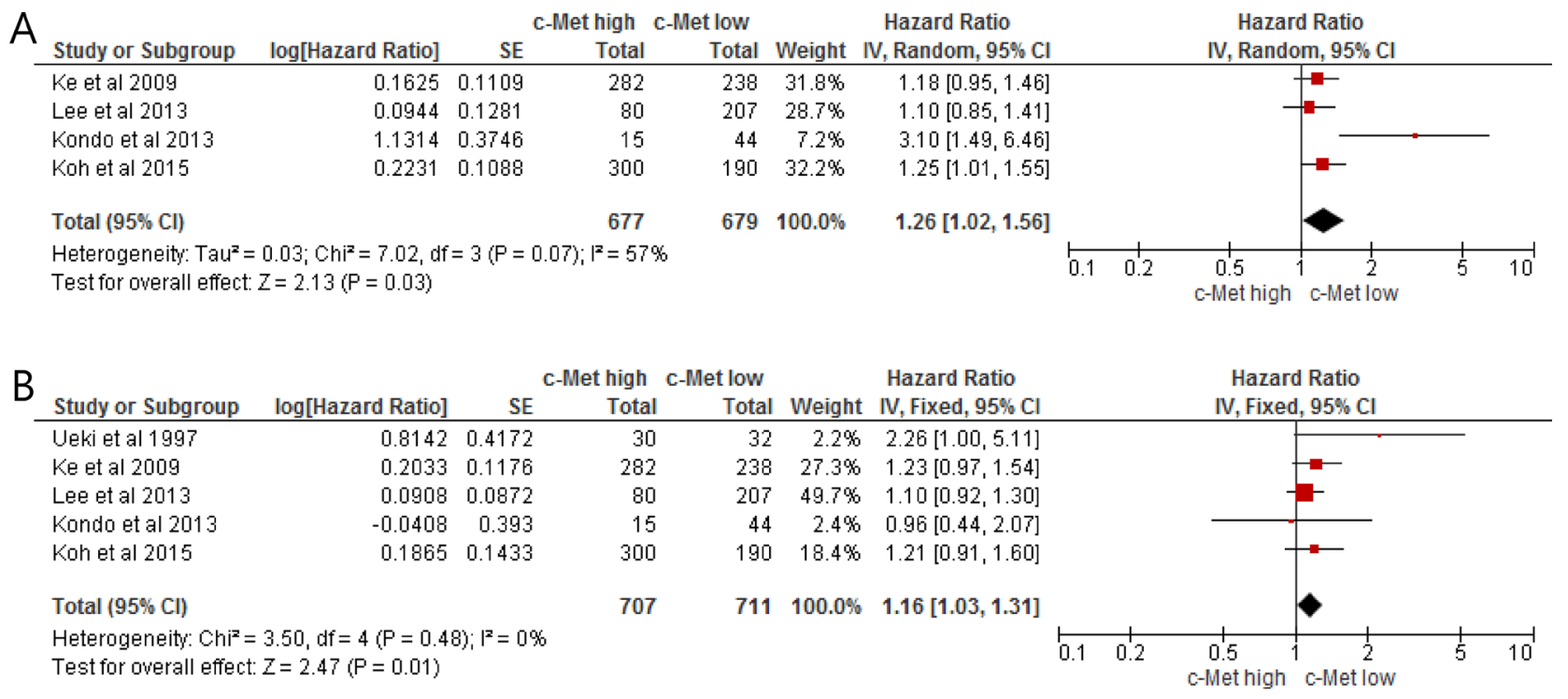

Figure 2: Forest plots of hazard ratios for relapse-free survival (A) and overall survival (B). 
c-Met plays a critical role in the pathogenesis and progression of many tumor types [10-13]. The enhanced expression of c-Met has also been detected in HCC [20-30]. Different molecular alterations have been found to determine c-Met activation: point mutations, gene amplifications, enhanced transcription, and autocrine activation [31]. In HCC, the aberrant activation of c-Met signaling results mainly from its overexpression due to enhanced transcription, rather than from gene mutations or amplifications [32]. The previous studies have suggested that c-Met overexpression is significantly associated with clinicopathological features of HCC, such as tumor grade [29], vascular invasion or thrombosis [23], tumor recurrence [30], metastases $[27,30]$, and worse RFS [27, 28] or OS [22-24]. A recent retrospective study with $194 \mathrm{HCC}$ patients treated by hepatic resection or microwave ablation found that c-Met overexpression was associated with unfavorable survival outcomes [22]. However, these results are contrary to the findings reported in other studies, in particular with respect to OS [26-28]. Recently, Lee et al. assessed c-Met expression and amplification in 287 patients with $\mathrm{HCC}$ and reported that c-Met overexpression was not significantly associated with any clinicopathological variable including tumor grade and size, vascular invasion, stage, RFS, and OS [26]. Because many studies had a small number of patients and adopted various methods and criteria for c-Met expression status [20-28], however, they could not draw a consensus regarding the prognostic value of c-Met expression.

In the current meta-analysis, we included studies comparing survival outcomes (RFS or OS) according to c-Met expression status (low vs. high). Patients with c-Met-high HCC showed significantly worse RFS $(\mathrm{HR}=1.26, P=0.03)$ and $\mathrm{OS}(\mathrm{HR}=1.16, P=0.01)$, compared with those with c-Met-low HCC. Our results indicate that high c-Met expression is an independent negative prognostic marker for recurrence and survival in HCC patients who received curative surgical resection. Several meta-analyses in other cancers have also demonstrated that high expression of c-Met is an adverse prognostic marker [14-17]. Thus, interference with c-Met activation may provide an effective therapeutic strategy for cancers with c-Met overexpression [33]. Based on the therapeutic rationale to target c-Met, various c-Met inhibitors are currently under active investigation in a variety of cancers, including HCC [9, 34-37]. Tivantinib, an oral selective c-Met receptor tyrosine kinase inhibitor, showed promising results as a second-line treatment in a randomized phase II trial of advanced HCC [36]. Interestingly, in the post hoc analysis of the c-Met high subgroup, patients treated with tivantinib showed better time-to-progression (median 2.7 vs. 1.4 months, $\mathrm{HR}=0.43, P=0.03$ ) and $\mathrm{OS}$ (median 7.2 vs. 3.8 months, $\mathrm{HR}=0.38, P=0.01)$, compared with those treated with placebo. Thus, patients with $\mathrm{HCC}$ overexpressing c-Met might be good candidates for treatment with c-Met inhibitors. In addition, in a recent randomized phase III trial of patients with advanced non-small-cell lung cancer, the efficacy of tivatinib in combination with erlotinib was also significantly associated with c-Met expression [34]. These results suggest the importance of indentifying predictive biomarkers for benefits in drug development.

However, the major limitation for development of c-Met inhibitors is that there is no consensus regarding the criteria for c-Met overexpression. Currently, a variety of methods (IHC, Western blot, fluorescence in situ hybridization, real-time quantitative PCR, or molecular invasion probe, etc) are used for assessing c-Met status, with no standardized criteria for overexpression. In addition, there are differences in the IHC criteria for high c-Met expression. The discrepancies in the prognostic impact of c-Met overexpression among studies might be attributable to the different methods and criteria for
A

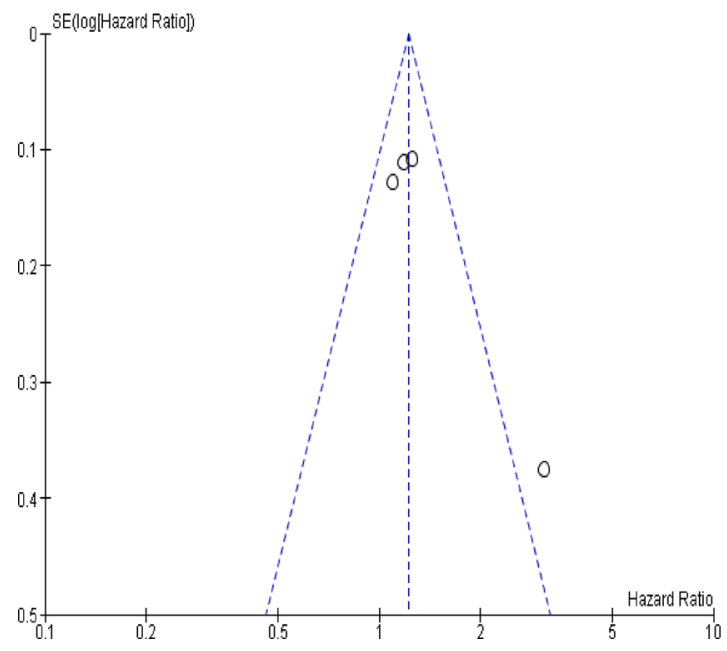

B

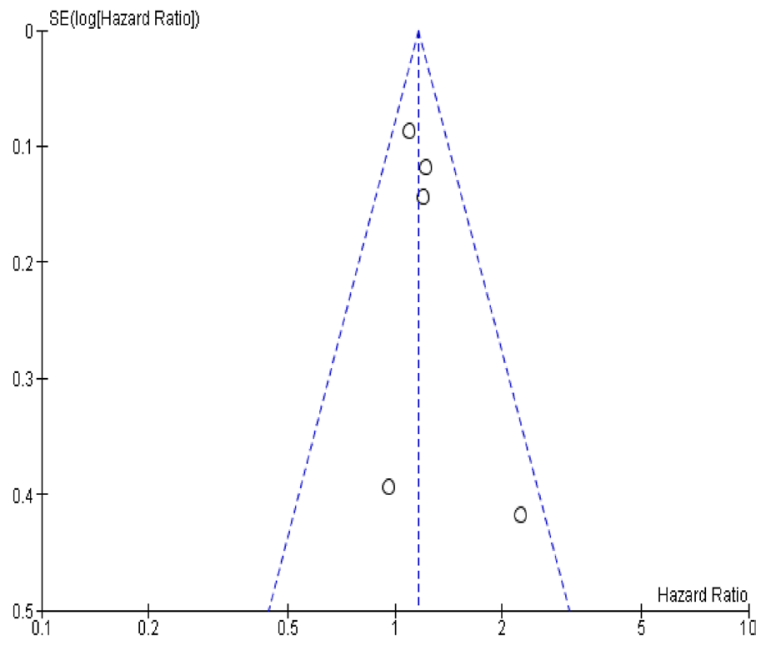

Figure 3: Funnel plots for publication bias regarding relapse-free survival (A) and overall survival (B). 
c-Met overexpression. Therefore, the definition of reliable criteria for Met-high status is essential to identify patients who will benefit most from MET-targeted therapies.

Our study has several inherent limitations that need to be noted. First, the meta-analysis included the small number of studies. Second, all the studies were retrospectively performed. Third, the five studies were all conducted in Asia. However, it is unlikely that there is a significant difference in the prognostic impacts of c-Met in HCC between Asia and Western countries. Forth, the studies used different methods (Western blot or IHC) and criteria to assess and stratify c-Met status, which might lead to the wide variation in the rate of c-Met overexpression among studies. Finally, papers published only in English were included, which might bias the results.

In conclusion, our meta-analysis demonstrates that c-Met overexpression is a significant adverse prognostic marker for recurrence and survival in patients who underwent surgical resection for HCC. However, larger prospective studies using standardized methods are still needed to verify the prognostic role of c-Met expression.

\section{MATERIALS AND METHODS}

\section{Publication searching strategy}

We performed this study according to the Preferred Reporting Items for Systematic Reviews and MetaAnalyses (PRISMA) guidelines [38]. A systematic computerized search of the electronic databases PubMed, Embase, and Google scholar (up to May 2017) was carried out. The search used the following keywords: 'c-Met' or 'Met' and 'hepatocellular carcinoma' or 'hepatoma' or 'liver neoplasm.' The related articles function in the PubMed was also used to identify all related articles.

\section{Inclusion criteria}

Eligible studies should meet the following inclusion criteria: (i) patients had a diagnosis of HCC and underwent curative surgical resection; (ii) RFS and/or OS were analyzed according to the c-Met expression status (low vs. high); (iii) HRs with $95 \%$ CIs for RFS or OS were reported or could be estimated from the data provided; (iv) articles were written in English.

\section{Data extraction}

Data extraction was carried out independently by two investigators (BJK and HSK). If these two authors did not agree, the principle investigator ( JHK) was consulted to resolve the dispute.

The following data were extracted from all eligible studies: first author's name, year of publication, country, number of patients, treatment, methodology for c-Met expression, the criteria used to dichotomize c-Met expression as 'high' or 'low', and HRs with their 95\% CIs for RFS or OS.

\section{Statistical analysis}

Statistical values were obtained directly from the original articles. When HR with its 95\% CIs was not provided, the Engauge Digitizer version 9.1 was used to estimate the needed data from Kaplan-Meier curves. The effect size of RFS and OS was pooled through HR and its 95\% CI. The heterogeneity across studies was examined by $Q$ statistic and the $I^{2}$ inconsistency test. The fixedeffect model (Mantel-Haenszel method) was selected for pooling homogeneous outcomes when $P \geq 0.1$ and $I^{2} \leq$ $50 \%$, and the random-effects model (DerSimonian-Laird method) was applied for pooling heterogeneous outcomes when $P<0.1$ and $I^{2}>50 \%$. The RevMan software version 5.2 was used to combine the data, and the final results were presented with HRs and their 95\% CIs. All reported $P$-values were two-sided and $P<0.05$ was considered statistically significant. Publication bias was assessed graphically by the funnel plot method [39].

\section{CONFLICTS OF INTEREST}

All authors have declared no competing interest.

\section{FUNDING}

This work had no specific funding support.

\section{REFERENCES}

1. Ferlay J, Soerjomataram I, Dikshit R, Eser S, Mathers C, Rebelo M, Parkin DM, Forman D, Bray F. Cancer incidence and mortality worldwide: sources, methods and major patterns in GLOBOCAN 2012. Int J Cancer. 2015; 136:359-86.

2. Jung KW, Won YJ, Oh CM, Kong HJ, Lee DH, Lee KH. Community of Population-Based Regional Cancer Registries. Cancer statistics in Korea: incidence, mortality, survival, and prevalence in 2014. Cancer Res Treat. 2017; 49:292-305.

3. Siegel RL, Miller KD, Jemal A. Cancer statistics, 2016. CA Cancer J Clin. 2016; 66:7-30.

4. Makuuchi M, Kosuge T, Takayama T, Yamazaki S, Kakazu T, Miyagawa S, Kawasaki S. Surgery for small liver cancers. Semin Surg Oncol. 1993; 9:298-304.

5. Nagashima I, Hamada C, Naruse K, Osada T, Nagao T, Kawano N, Muto T. Surgical resection for small hepatocellular carcinoma. Surgery. 1996; 119:40-5.

6. Kumada T, Nakano S, Takeda I, Sugiyama K, Osada T, Kiriyama S, Sone Y, Toyoda H, Shimada S, Takahashi M, Sassa T. Patterns of recurrence after initial treatment 
in patients with small hepatocellular carcinoma. Hepatology.1997; 25:87-92.

7. Llovet JM, Ricci S, Mazzaferro V, Hilgard P, Gane E, Blanc JF, de Oliveira AC, Santoro A, Raoul JL, Forner A, Schwartz M, Porta C, Zeuzem S, et al. Sorafenib in advanced hepatocellular carcinoma. N Engl J Med. 2008; 359:378-90.

8. Cheng AL, Kang YK, Lin DY, Park JW, Kudo M, Qin S, Chung HC, Song X, Xu J, Poggi G, Omata M, Pitman Lowenthal S, Lanzalone S, et al. Sunitinib versus sorafenib in advanced hepatocellular cancer: results of a randomized phaseIII trial. J Clin Oncol. 2013; 31:4067-75.

9. Qi XS, Guo XZ, Han GH, Li HY, Chen J. MET inhibitors for treatment of advanced hepatocellular carcinoma: A review. World J Gastroenterol. 2015; 21:5445-53.

10. Furge KA, Zhang YW, Vande Woude GF. Met receptor tyrosine kinase: enhanced signaling through adapter proteins. Oncogene. 2000; 19:5582-9.

11. Rosário M, Birchmeier W. How to make tubes: signaling by the Met receptor tyrosine kinase. Trends Cell Biol. 2003; 13:328-35.

12. Blumenschein GR Jr, Mills GB, Gonzalez-Angulo AM. Targeting the hepatocyte growth factor-cMET axis in cancer therapy. J Clin Oncol. 2012; 30:3287-96.

13. Zhang YW, Su Y, Volpert OV, VandeWoude GF. Hepatocyte growth factor/scatter factor mediates angiogenesis through positive VEGF and negative thrombospondin 1 regulation. Proc Natl Acad Sci USA. 2003; 100:12718-23.

14. Yan S, Jiao X, Zou H, Li K. Prognostic significance of c-Met in breast cancer: a meta-analysis of 6010 cases. Diagn Pathol. 2015; 10:62.

15. Pyo JS, Kang G, Cho WJ, Choi SB. Clinicopathological significance and concordance analysis of c-MET immunohistochemistry in non-small cell lung cancers: A meta-analysis. Pathol Res Pract. 2016; 212:710-6.

16. Yu S, Yu Y, Zhao N, Cui J, Li W, Liu T. C-Met as a prognostic marker in gastric cancer: a systematic review and meta-analysis. PLoS One. 2013; 8:e79137.

17. Liu Y, Yu XF, Zou J, Luo ZH. Prognostic value of c-Met in colorectal cancer: a meta-analysis. World J Gastroenterol. 2015; 21:3706-10.

18. Peng J, Qi S, Wang P, Li W, Liu C, Li F. Diagnosis and prognostic significance of c-Met in cervical cancer: a metaanalysis. Dis Markers. 2016; 2016:6594016.

19. Furukawa T, Duguid WP, Kobari M, Matsuno S, Tsao MS. Hepatocyte growth factor and Met receptor expression in human pancreatic carcinogenesis. Am J Pathol. 1995; 147:889-95.

20. Chu JS, Ge FJ, Zhang B, Wang Y, Silvestris N, Liu LJ, Zhao CH, Lin L, Brunetti AE, Fu YL, Wang J, Paradiso A, $\mathrm{Xu}$ JM. Expression and prognostic value of VEGFR-2, PDGFR- $\beta$, and c-Met in advanced hepatocellular carcinoma. J Exp Clin Cancer Res. 2013; 32:16.

21. Ang CS, Sun MY, Huitzil-Melendez DF, Chou JF, Capanu M, Jarnagin W, Fong Y, Dematteo RP, D’Angelica
M, Allen P, Chen CT, O'Reilly EM, Weiser MR, et al. c-MET and HGF mRNA expression in hepatocellular carcinoma: correlation with clinicopathological features and survival. Anticancer Res. 2013; 33:3241-5.

22. Wang ZL, Liang P, Dong BW, Yu XL, Yu DJ. Prognostic factors and recurrence of small hepatocellular carcinoma after hepatic resection or microwave ablation: a retrospective study. J Gastrointest Surg. 2008; 12:327-37.

23. Zhuang PH, Xu L, Gao L, Lu W, Ruan LT, Yang J. Correlations of microvascular blood flow of contrast-enhanced ultrasound and HGF/c-Met signaling pathway with clinicopathological features and prognosis of patients with hepatocellular carcinoma. Onco Targets Ther. 2017; 10:847-57.

24. Ueki T, Fujimoto J, Suzuki T, Yamamoto H, Okamoto E. Expression of hepatocyte growth factor and its receptor c-met proto-oncogene in hepatocellular carcinoma. Hepatology. 1997; 25:862-6.

25. Ke AW, Shi GM, Zhou J, Wu FZ, Ding ZB, Hu MY, Xu Y, Song ZJ, Wang ZJ, Wu JC, Bai DS, Li JC, Liu KD, et al. Role of overexpression of CD151 and/or c-Met in predicting prognosis of hepatocellular carcinoma. Hepatology. 2009; 49:491-503.

26. Lee SJ, Lee J, Sohn I, Mao M, Kai W, Park CK, Lim HY. A survey of c-MET expression and amplification in 287 patients with hepatocellular carcinoma. Anticancer Res. 2013; 33:5179-86.

27. Kondo S, Ojima H, Tsuda H, Hashimoto J, Morizane C, Ikeda M, Ueno H, Tamura K, Shimada K, Kanai Y, Okusaka T. Clinical impact of c-Met expression and its gene amplification in hepatocellular carcinoma. Int J Clin Oncol. 2013; 18:207-13.

28. Koh YW, Park YS, Kang HJ, Shim JH, Yu E. MET is a predictive factor for late recurrence but not for overall survival of early stage hepatocellular carcinoma. Tumour Biol. 2015; 36:4993-5000.

29. D'Errico A, Fiorentino M, Ponzetto A, Daikuhara Y, Tsubouchi H, Brechot C, Scoazec JY, Grigioni WF. Liver hepatocyte growth factor does not always correlate with hepatocellular proliferation in human liver lesions: its specific receptor c-met does. Hepatology. 1996; 24:60-4.

30. Daveau M, Scotte M, François A, Coulouarn C, Ros G, Tallet Y, Hiron M, Hellot MF, Salier JP. Hepatocyte growth factor, transforming growth factor alpha, and their receptors as combined markers of prognosis in hepatocellular carcinoma. Mol Carcinog. 2003; 36:130-41.

31. Danilkovitch-Miagkova A, Zbar B. Dysregulation of Met receptor tyrosine kinase activity in invasive tumors. J Clin Invest. 2002; 109:863-7.

32. Granito A, Guidetti E, Gramantieri L. c-MET receptor tyrosine kinase as a molecular target in advanced hepatocellular carcinoma. J Hepatocell Carcinoma. 2015; 2:29-38.

33. Peters S, Adjei AA. MET: a promising anticancer therapeutic target. Nat Rev Clin Oncol. 2012; 9:314-26.

34. Scagliotti G, von Pawel J, Novello S, Ramlau R, Favaretto A, Barlesi F, Akerley W, Orlov S, Santoro A, Spigel D, Hirsh 
V, Shepherd FA, Sequist LV, et al. Phase III multinational, randomized, double-blind, placebo-controlled study of tivantinib (ARQ 197) plus erlotinib versus erlotinib alone in previously treated patients with locally advanced or metastatic nonsquamous non-small-cell lung cancer. J Clin Oncol. 2015; 33:2667-74.

35. Brandes F, Schmidt K, Wagner C, Redekopf J, Schlitt HJ, Geissler EK, Lang SA. Targeting cMET with INC280 impairs tumour growth and improves efficacy of gemcitabine in a pancreatic cancer model. BMC Cancer. $2015 ; 15: 71$.

36. Santoro A, Rimassa L, Borbath I, Daniele B, Salvagni S, Van Laethem JL, Van Vlierberghe H, Trojan J, Kolligs FT, Weiss A, Miles S, Gasbarrini A, Lencioni M, et al. Tivantinib for second-line treatment of advanced hepatocellular carcinoma: a randomised, placebo-controlled phase 2 study. Lancet Oncol. 2013; 14:55-63.
37. Xiang Q, Chen W, Ren M, Wang J, Zhang H, Deng DY, Zhang L, Shang C, Chen Y. Cabozantinib suppresses tumor growth and metastasis in hepatocellular carcinoma by a dual blockade of VEGFR2 and MET. Clin Cancer Res. 2014; 20:2959-70.

38. Panic N, Leoncini E, de Belvis G, Ricciardi W, Boccia S. Evaluation of the endorsement of the preferred reporting items for systematic reviews and meta-analysis (PRISMA) statement on the quality of published systematic review and meta-analyses. PLoS One. 2013; 8:e83138.

39. Sterne JA, Sutton AJ, Ioannidis JP, Terrin N, Jones DR, Lau J, Carpenter J, Rücker G, Harbord RM, Schmid CH, Tetzlaff J, Deeks JJ, Peters J, et al. Recommendations for examining and interpreting funnel plot asymmetry in meta-analyses of randomised controlled trials. BMJ. 2011; 343:d4002. 